\title{
DOCUMENTOS - IN MEMORIAM
}

\section{José Vicente Asuar Puigrrós (Santiago de Chile, 20 de julio, 1933-11 de enero, 2017)}

De manera repentina nos dejó una de las figuras claves del modernismo musical chileno, encontrándose en pleno proceso de reivindicación y revalorización total de su figura y del lugar que ocupó en la historia musical del país. Proceso que comenzó hace aproximadamente una década. Toda información de trasfondo y contexto en torno a la importancia de José Vicente Asuar como pionero de la electroacústica, a nivel no solo local sino que mundial, está ampliamente documentado. Tanto en trabajos de investigación como el que realizó Federico Schumacher a mediados de la década pasada acerca del desarrollo de la electroacústica en Chile, pasando por las selectivas entrevistas que el maestro otorgó, hasta llegar a la película documental Variaciones Espectrales, dirigida por Carlos Lértora y estrenada en 2013 .

Aquel trabajo fílmico tomó su título de aquel hito creativo de 1959, insoslayable a la hora de recordar al maestro. Las Variaciones Espectrales conforman la primera pieza puramente electrónica del país, y hasta hoy no deja de asombrar por su sentido de forma, su fineza tímbrica, y porque muestra un grado de manejo tecnológico y de medios a la par de lo que sucedía en ese mismo momento en el hemisferio norte, barriendo al mismo tiempo con los monocromos ejercicios concretos de Juan Amenábar y León Schidlowsky realizados un poco antes.

Así como Asuar desarrolló el lenguaje electrónico, acusmático y todo lo relacionado con la gran rama de la electroacústica, fue también un avanzado en lo que se refiere específicamente a la música computacional, primero en la Universidad de Chile, y posteriormente de manera personal, construyendo su propio microcomputador, el legendario COMDASUAR, antes de los PC, antes del midi, y obteniendo sonoridades afines a las de un sintetizador Moog. Esta aventura, propia y solitaria, fue generada por su abrupta salida de la Universidad de Chile, que tuvo un profundo efecto en el compositor, quien se volvió una figura aislada, rodeada de misterio.

La pelea que tuvo con Juan Amenábar, de la que no se sabe mucho en verdad, hace recordar un poco a lo vivido por Enrique Soro con Domingo Santa Cruz. Ya llegará el momento para musicógrafos y musicólogos de enfrentar de manera franca aquella ingrata situación que hizo de Asuar un outsider, ninguneado e invisibilizado por la oficialidad académica.

Por supuesto, esa invisibilidad fue relativa. A pesar de dejar la composición en 1989, su revalorada figura desde comienzos de la década pasada sirvió de inspiración para la gran cantidad de compositores actuales que se dedican a la música acusmática, incluyendo a creadores que no tienen formación de conservatorio. No fue ese el caso de Asuar, que estudió con Jorge Urrutia-Blondel, y posteriormente en Alemania junto con Boris Blacher, datos que lamentablemente no aparecen en el mencionado documental. 
Llegamos así a un punto que faltaba explorar del compositor, ausente en todos los homenajes, actos y artículos promovidos por sus admiradores desde el campo de la creación electroacústica, y es que Asuar compuso abundante música más allá de la acusmática y de los computadores. Sí, Asuar escribió música. Y es en este punto donde el presente obituario adquiere tintes personales para quien redacta.

Sabiendo de la existencia de todo un canon de música en notación tradicional de la pluma de Asuar, comencé un trabajo indagatorio en ese ámbito, para que nos llevara de una vez por todas a tener una imagen completa del compositor. Tanto en la Biblioteca Nacional como en el archivo de la Facultad de Artes de la Universidad de Chile solo se encontraban tres de estas obras, Formas (1970), para orquesta sinfónica, Invenciones (1955), para piano, y el ciclo para canto y piano Lamentos haitianos (1955).

Al notar el innegable valor musical de esta terna, rápidamente me ocupé de encontrarles un lugar entre los intérpretes, confiando en que eso ayudaría también a que el compositor fuese considerado para el Premio Nacional de Artes, al que efectivamente postuló en 2016. Fue así que ese mismo año, en agosto, la Orquesta Sinfónica de Chile (que ahora agregó "Nacional" a su nombre) interpretó Formas después de 45 años de su estreno. Unos meses antes, la soprano Camila García cantó los Lamentos dentro de la temporada de conciertos de la Academia Chilena de Bellas Artes. Pero había más. Hay más.

Las noticias de estas interpretaciones permitieron ganarme la confianza del reacio Asuar, quien, pese a sus aprensiones iniciales, me ayudó en la confección, que yo ya había iniciado, del catálogo completo de sus obras. Finalmente, este catálogo tiene su lugar en el presente número de la RMCh, en la versión que circula en línea. De igual forma, poco a poco fui convenciéndolo de la importancia, de la necesidad, de rescatar el resto de sus partituras, que estaba en su poder, para que estuviesen al alcance de músicos, musicólogos, musicógrafos, o de cualquier otro interesado. Hasta que, de un día para otro, sacó de su bodega aquel tesoro.

Finales de diciembre. Luego de mostrarle al maestro Asuar el Archivo de Música de la Biblioteca Nacional, y el cuidado que allí se tiene con el patrimonio musical chileno, él decide donar todas sus partituras. Se notaba en su mirada un brillo especial, uno que hacía pensar si en el fondo de su ser quizás concebía la idea de volver algún día a la composición. Pero, a mediados de enero, un paro cardiaco termina con su vida.

Ahora nos queda el legado de quien demostró ser uno de los más imaginativos compositores chilenos. Ya en su temprana Cantata 1951 experimentó con aleatoriedad y un tipo de improvisación orquestal que luego sería común en un Fernando García o un León Schidlowsky. En Estudios rítmicos (1953) hay un presentimiento de lo que sería después el minimalismo. Y un poco antes de estos ejemplos, Asuar entonces soñaba con la realización de música con medios puramente electrónicos, cuando recién en Francia se gestaba la denominada "música concreta". Mucha de la música "escrita" de Asuar no ha sido interpretada todavía. Entre sus composiciones, una vasta obra sinfónica titulada Heterofonías, de enormes ambiciones estéticas, que posee un florido espectro sonoro, tímbrico, y donde asoman proximidades con la música de Boulez. Ya llegará el momento para cada una de estas piezas, que ahora están a la mano.

Finalmente, hay que recordar que Asuar fue un activo colaborador de la RMCh por muchos años, y sus escritos aparecen también referidos en este homenaje. Poseedor de una pluma clara, sincera, y muy asertiva, es altamente recomendable leer sus impresiones que dan espacio a un grado de sensibilidad humana que lo hacen ameno, cercano, lejos de elucubraciones estériles o impenetrables. La versión digital del presente número anexa dos escritos de factura reciente, que muestran a un viejo maestro, rememorando 
momentos significativos, o reflexionando acerca de un tema tan interesante como la honestidad en la música.

Le quedamos debiendo el Premio Nacional. Pese a la indiferencia y las ingratitudes que recibió, tal como Soro, su legado se ha ido imponiendo por su auténtico valor, por su trascendencia y claramente por su influencia en las posteriores generaciones.

Hasta siempre maestro.

Álvaro Gallegos $M$. alvarogallegosm@gmail.com 